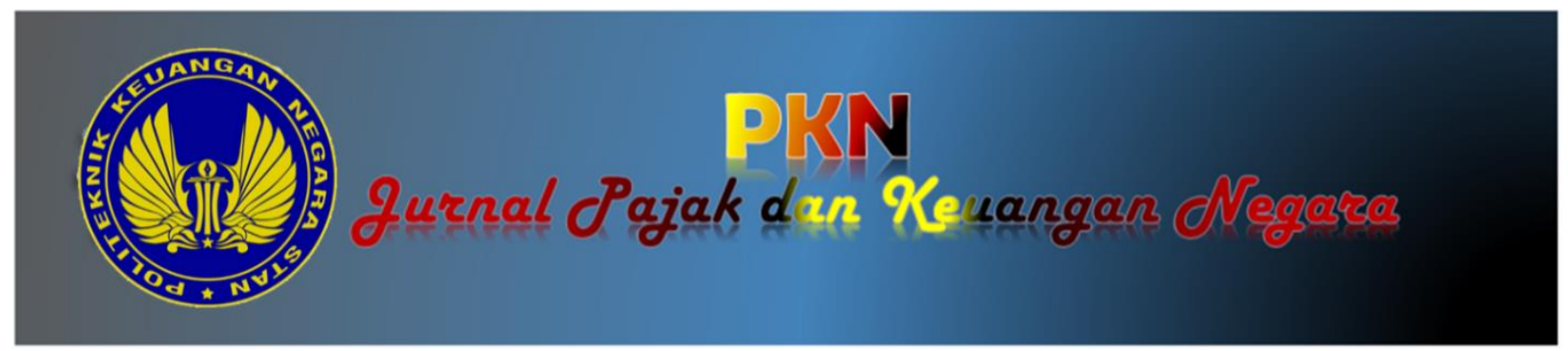

\title{
Measuring Government Tax Effort: Value Added Tax Elasticity and Buoyancy
}

\author{
Hanafi Risdiawan, \\ Directorate General of Tax, Ministry of Finance \\ Nurhidayati, \\ STAN Polytechnic of State Finance \\ Alamat Korespondensi: [nurhidayati@pknstan.ac.id]
}

\section{Article Info}

Article history:

Received: 17 Juni 2020

Accepted: 23 September 2020

Published:

\section{Keywords:}

elasticity, buoyancy, tax effort

\begin{abstract}
Value Added Tax (VAT) elasticity and buoyancy calculations can help identify weaknesses in the tax structure and formulate better tax strategies. The concept of tax elasticity and buoyancy also produces estimates of the efficiency of the tax system, namely the ability to be able to mobilize tax revenue with or without changes in tax policy. In calculating tax buoyancy, this research used linear regression. Dummy variable method was used to measure tax elasticity. Based on this study, VAT is inelastic but relatively buoyant. The coefficient of elasticity of VAT revenue is less than one. This explains that VAT revenue growth is not responsive to the growth of the tax base.
\end{abstract}

\begin{abstract}
Abstrak
Elastisitas dan bouyansi Pajak Pertambahan Nilai (PPN) dapat membantu mengidentifikasi kelemahan dalam struktur pajak dan merumuskan strategi pajak yang lebih baik. Konsep elastisitas dan daya apung pajak juga menghasilkan perkiraan efisiensi sistem pajak, yaitu kemampuan untuk dapat memobilisasi pendapatan pajak dengan atau tanpa perubahan kebijakan pajak. Dalam menghitung pajak apung, penelitian ini menggunakan regresi linier. Metode variabel dummy digunakan untuk mengukur elastisitas pajak. Berdasarkan penelitian ini, PPN tidak elastis tetapi relatif ringan. Koefisien elastisitas pendapatan PPN kurang dari satu. Ini menjelaskan bahwa pertumbuhan pendapatan PPN tidak responsif terhadap pertumbuhan basis pajak.
\end{abstract}




\section{INTRODUCTION}

Value Added Tax is the tax that most influences a country's economic growth (Gale and Haris, 2011). VAT characteristics that are easy to administer and objectively make VAT a potential source of revenue for the government. Increasing the contribution of three main sectors (manufacturing, wholesale and retail trade, and agriculture and forestry) to Gross Domestic Product (GDP) can be a potential tax base from VAT. Consumption activities for developing countries like Indonesia is one of the main economic activities in society (Wijayanti, 2015). Increasing consumption activities increase the flow of goods and services that will affect VAT revenue. Thus, the base of VAT is extremely broad.

Figure 1 Growth Ratio of VAT to GDP in 2007 to 2016

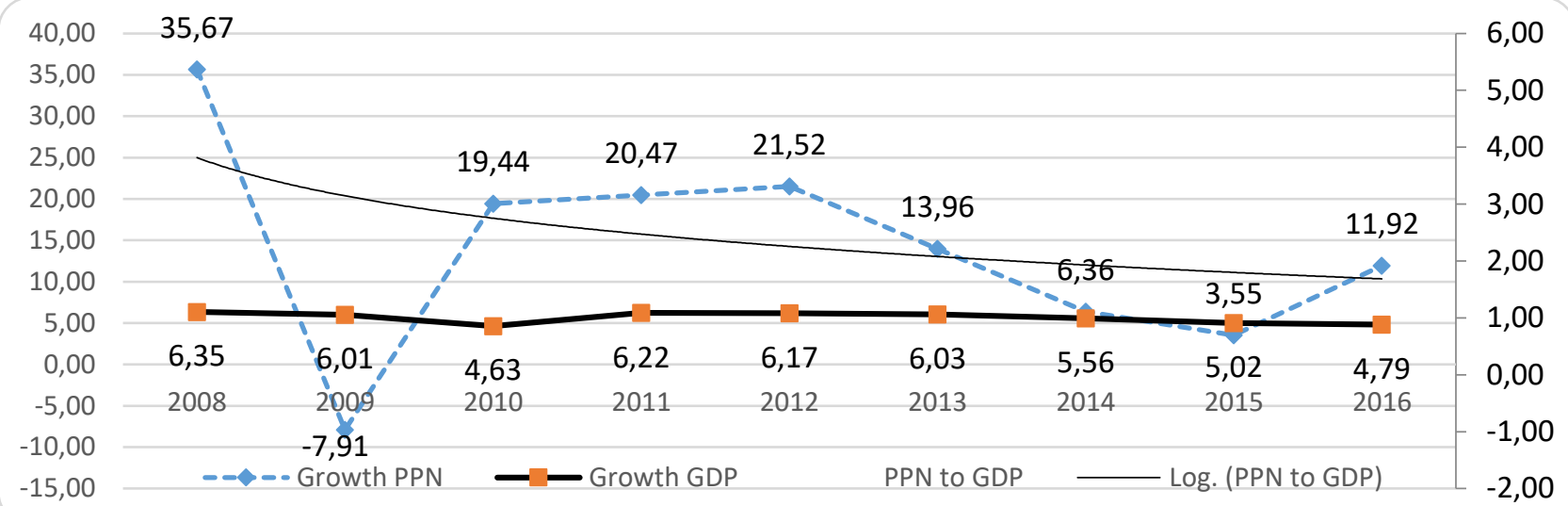

Source: Processed from BPS and LKPP data

Based on the figure 1, the growth rate of VAT to the growth in GDP experienced a downward trend over the last ten years. In addition, the contribution of VAT is still not optimal. Normatively, Indonesia should be able to achieve a VAT contribution of 4 percent of GDP given the prevailing VAT rate in Indonesia is 10 percent (OECD). According to research conducted by Cnossen (1989) in countries Organization for Economic Co-operation and Development (OECD), the ideal conditions of a tax system based on its contribution to GDP amounted to 0.4 percent of the applicable rates. However, the contribution of VAT to Indonesia's GDP was 3.75 percent in 2013 (Sugana and Hidayat, 2014). Although Indonesia's economic growth has been relatively stable over the past 10 years, VAT growth has been on a large downward trend.

VAT revenue that have not been fully optimally administered also appear in VAT performance. VAT performance in Indonesia is still relatively low when compared to some countries in Southeast Asia. According to Sugana and Hidayat's research (2014), the performance of VAT in Indonesia in 2013 was 65.9 percent. This value is obtained through a comparison between VAT and consumption. This is farless than the performance of Singapore, Thailand and Vietnam VAT. The three countries have VAT performance above 90 percent. -

The important thing to be observed is the policy related to VAT. The VAT policy is closely related to the VAT tax base whether it can expand the tax base or erode the tax base. Worldbank's tax experts reveal a VAT exemption policy erode the tax base around 40 percent (Ardiansyah, 2015). This condition results in the entire supply chain of goods or services which will lead to the potential loss of VAT revenue. Second things that can be explored are whether government policies related to VAT appropriate to maximize the VAT revenue base (Sjafri, 2006).

One way to estimate the value of tax policy is to measure tax buoyancy and tax elasticity (Jenkins, Kuo, and Shukla, 2000). Tax buoyancy is an indicator to measure how efficient and responsive tax revenue is in following GDP growth by incorporating elements of taxation policies that occur during the year (Nurhidayati, 2015). In line with the concept of tax buoyancy, the concept of tax elasticity measures how elastic the tax base is converted to tax revenue by issuing an element of tax discretion. Tax elasticity and buoyancy will be better expressed by breaking down all types of taxes into each type of tax (Jenkins, Kuo, and Shukla, 2000). Both of these concepts are useful in evaluating the ability of tax revenue both in terms of tax policy and the development of the tax base (Priambodo, 2013).

Measurement of VAT elasticity and buoyancy can help identify weaknesses in the tax structure and formulate better tax strategies (Jenkins, and Kuo, 2000). The ideal condition of a tax system is when the tax elasticity and buoyancy are equal to or more than one. The concept of tax elasticity and buoyancy also produces estimates of the efficiency of the tax system, namely the ability to be able to mobilize tax revenue with or without changes in tax policy (Cotton, 2012). If the value of tax buoyancy is greater than the value of tax elasticity, it can be said that the government has made efforts to increase tax revenue. Government Tax Effort is a measure of government efforts to improve the administration of the taxation system in a certain period of time as a result of implementing a policy. Government Tax Effort is expressed by the difference between the value of tax buoyancy and 
tax elasticity (Lawrence, 2011). This study complements the previous research by increasing the range of the study period and the method for calculating the tax elasticity.

\section{METHOD}

In calculating tax buoyancy, linear regression is used. The statistical model used is multiple linear regression model that is a linear relationship between the independent variable $(X)$ with the dependent variable (Y). The multiple regression formula used in calculating the tax buoyancy is as follows:

$$
\ln \Delta Y=a+b \ln \Delta X+e
$$

Where:

$\begin{array}{ll}\text { In } \Delta \mathrm{Y} & : \text { Changes in VAT Revenue } \\ a & : \text { Constants } \\ b & : \text { Buoyancy Coefficient } \\ \ln \Delta \mathrm{X} & : \text { Changes in GDP } \\ e & : \text { error terms }\end{array}$

Natural logarithms (In) are used in this study to bridge if there are two variables whose values are too large (Sjafri, 2006). In addition, an important assumption is that income elasticity is constant throughout the income range. This constancy requires that a proportional tax response for one percent of income will be the same, regardless of income level (Nurhidayati, 2013). The regression test determine $b$ as a measure of tax buoyancy in accordance with research Choudhry (1979).

In calculating tax elasticity, the method used is the Dummy Variable method. This method uses a dummy variable to study the impact of taxation policy through an econometrics. The dummy variable is employed to calculate tax elasticity. both changes occur due to the rise and fall of the number and value of tax objects without affecting the tendency of taxpayers due to tax discretion (Priambodo, 2013). The tax elasticity formula is as follows. $\operatorname{Ln} \Delta Y=a+b \ln \Delta X+c D 1+d D 2+e D 3+e$

\section{Where:}

$\begin{array}{ll}\text { In } \Delta \mathrm{Y} & \text { : Changes in VAT Revenue } \\ \mathrm{a} & \text { : Constants } \\ \mathrm{b} & \text { : Regression Coefficient } \\ \text { In } \Delta \mathrm{X} & \text { : Changes in GDP } \\ \mathrm{D} & \text { : Dummy variable }\end{array}$

D1 : Amendment to the 1994 VAT Law, value 0 for the year before a tax discretion policy and value of 1 for the year after a tax discretion policy

D2 : Amendment of the 2000 VAT Act, value 0 for the year before a tax discretion policy and value of 1 for the year after a tax discretion policy

D3 : Amendment of the 2009 VAT Act, value 0 for the year before a tax discretion policy and value of 1 for the year after a tax discretion policy e : error terms

The calculation of Government Tax Effort (GTE) refers to the research of Bothole and Agiobenebo (2006),
Lawrence (2011) and Thac and Lim (1984). This GTE concept is basically the difference between the coefficient of buoyancy and tax elasticity. A significant difference between the coefficient of buoyancy and elasticity shows that there is a strong and large effort to collect tax revenue through tax policy. The formula for calculating GTE is as follows.

$$
\mathrm{GTE}=\frac{(\mu-r)}{r} \times 100 \%
$$

Where:

GTE : Government Tax Effort

$r \quad$ : the coefficient of elasticity of VAT

$\mu \quad$ : VAT buoyancy coefficient

\section{RESULTS AND DISCUSSION}

The VAT elasticity test is to measure how elastic the VAT revenue towards its tax base without the influence of tax policy. The VAT Buoyancy Test that was carried out in the previous stage measures how responsive tax revenue has changed to its tax base due to a change in policy. Meanwhile, the effect of tax policy must be eliminated in calculating the VAT elasticity.

There are several methods that can be used to measure VAT elasticity. The VAT elasticity test in this study uses a dummy variable model introduced by Singer (1968). The dummy variable method in equation modeling is considered more accurate when there are relatively rare tax policy changes. After the enactment of the VAT Law in 1985 , Indonesia only experienced three changes to the VAT Law namely in 1994, 2000 and 2009.

Table 1 Results of Regression Equations with Dummy Variables

\begin{tabular}{l|llll} 
Variable & Coefficient & Std. Error & $t$-Statistics & Prob. \\
\hline LN_PDB_Riil & .826553 & 0.339691 & 2.433248 & 0.0216 \\
D1 & 0.001578 & 0.593970 & 0.002657 & .9979 \\
D2 & 0.598967 & 0.614017 & 0.975490 & 0.3377 \\
D3 & 0.514197 & 0.608584 & 0.844907 & 0.4053 \\
C & $-2,968411$ & 3,977114 & $-0,746373$ & 0.4617
\end{tabular}

Source: Author processed by EViews 9

Table 1 explains the results of VAT elasticity testing using the dummy variable method. Based on table 2, the regression equation shows a probability (F-statistic) of 0.0000 or smaller than the 5 percent significance level so that it can be concluded that the independent variable has a significant effect on the dependent variable. The coefficient of determination of the model showed 87.14 percent value that indicates the variable VAT can be explained by the independent variables, namely GDP variable, the variable dummy VAT Law of 1994, the variable dummy VAT Law in 2000 and a variable dummy VAT Law 2009 of 87.14 percent. Meanwhile, the difference from the determination coefficient of 12.86 percent is explained by other variables besides the variables used in this study.

Table 2 F Test Results with Dummy Variables

\begin{tabular}{ll}
\hline R-Squared & .871460 \\
\hline Adjusted R-Squared & 0.853097 \\
\hline
\end{tabular}




\begin{tabular}{ll} 
F-Statistics & 47,45766 \\
\hline Prob (F-Statistic) & 0.00 million
\end{tabular}

Source: Author processed by EViews 9

The linear regression equation according to table 1 can be explained in the following equation model. The research model explains that the InPDB coefficient has a positive value which indicates that the GDP variable has a positive effect on VAT acceptance.

Ln VAT $=-2.968411+0.826 \ln G D P+0.001 D 1+0.598 D 2$ $+0.514 D 3+e$

The level of elasticity is indicated by the coefficient $b$. The coefficient $b$ in the equation model is 0.826553 . This explains that each change of 1 percent of GDP will cause a change in VAT revenue of 0.826553 percent. This value explains that the acceptance of VAT is less elastic or inelastic where the elasticity coefficient value is less than one. The results of the calculation of elasticity and buoyancy show that VAT receipts are inelastic but relatively buoyant. This is consistent with the second hypothesis in this study that the coefficient of VAT buoyancy is greater than the coefficient of VAT elasticity.

The linear regression shows that the VAT buoyancy rate is 1.08064 . It means that every 1 percent change in GDP will cause an increase in VAT of 1.08064 percent. This result indicates that VAT revenue is buoyant.

Table 3 Result of Regression for Buoyancy

Variabel Koefisien Std. Eror t-Statistik Prob.

\begin{tabular}{c|cccc}
\hline$L N_{-} P D B \_R i i l$ & 1,080684 & 0,077182 & 14,00173 & 0,0000 \\
$C$ & $-6,041689$ & 1,067906 & $-5,657511$ & 0,0000
\end{tabular}

Source: Author processed by EViews 9

$\ln P P N=-6,041689+1,080683 \ln P D B+\varepsilon$

The difference between the coefficient of tax buoyancy and tax elasticity is expressed as a measure of Government Tax Effort (Lawrence, 2011). Government Tax Effort (GTE) is a measure of efforts to improve the tax administration system by the government as a result of implementing a tax policy. GTE measurement is the difference in buoyancy with elasticity and is notated as a percentage. The results of Government Tax Effort measurements during the study period are as follows.

$$
\begin{gathered}
G T E=\left(\frac{1,080683-0,826553}{0,826553}\right) \times 100 \% \\
G T E=30,75 \%
\end{gathered}
$$

Based on the calculation, the value of the Government Tax Effort for VAT during the study period from 1985 to 2017 was 30.75 percent. This explains that the policy change and improvement in the quality of VAT administration implemented by the government increased VAT revenue by 30.75 percent from the automatic growth of VAT revenue during the study period.

The results of the research on the elasticity and buoyancy of Value Added Tax in Indonesia during 1985 to 2017 are in accordance with table 3. Changes in Gross Domestic Product (GDP) significantly influence changes in revenue from Value Added Tax (VAT). The VAT buoyancy rate indicates 1.081 and the VAT elasticity rate is 0.826 . The elasticity coefficient shows a smaller value than the coefficient of buoyancy. The coefficient of elasticity of 0.826 indicates that VAT growth is inelastic. VAT receipts do not automatically increase following an increase in GDP. The coefficient of buoyancy with a number of 1.081 indicates that policy changes have a positive impact on VAT revenue. VAT receipts become buoyant. The results of this study are consistent with Nurhidayati's (2015) research, in which VAT receipts are also not elastic but are relatively buoyant. Nurhidayati's research results (2015) showed an elasticity coefficient of 0.632 and a buoyancy coefficient of 1.076. Thus, the two hypotheses in this study are accepted, namely changes in GDP have a significant effect on changes in VAT revenue and the coefficient on VAT buoyancy is greater than the coefficient of VAT elasticity.

Table 4 VAT Buoyancy and Elasticity Levels for the Period of 1985 to 2017

\begin{tabular}{llll}
\hline & Buoyancy & Elasticity & GTE \\
\hline Aggregate & 1,081 & 0.826 & 0.3075 \\
\hline
\end{tabular}

Source: Processed from the calculation of VAT buoyancy and elasticity

The VAT buoyancy coefficient that is greater than the VAT elasticity coefficient indicates that the government has made efforts to increase VAT revenue. These efforts can be measured through the value of Government Tax Effort. During the 1985 to 2017 period, the size of the Government Tax Effort (GTE) reached 30.75 percent. This value explains that the policy adopted including improving the quality of tax administration, has been able to increase VAT revenue by 30.75 percent of the automatic tax growth. The growth in VAT revenues has become more responsive than the automatic growth of the tax base as a result of the impact of applying tax policies. In aggregate, the policies implemented have succeeded in increasing tax revenue. However, a GTE value below one indicates that tax revenue can be increased through improved tax structures (Lawrence, 2011). It can be said, government policy on VAT has not been fully effective. There is still a potential tax and tax base that has not yet been fully reached by the tax administration or tax policy. This is in line with research conducted by Sugana and Hidayat (2014) that the productivity of VAT in Indonesia is still below 40 percent.

\section{Level of Elasticity and VAT Buoyancy}

Tax buoyancy and elasticity are general indicators that can be used to measure the level of sensitivity or responsiveness of tax revenue to the tax base (Nurhidayati, 2015). This value can describe the productivity of tax revenue. Comparing the coefficient of buoyancy and the coefficient of elasticity indicate the role of policy (Milwood, 2012). If the coefficient of buoyancy is greater than the coefficient of elasticity, tax policy is assumed to have a greater contribution than automatic acceptance of the tax 
base. However, if the elasticity coefficient exceeds the coefficient of buoyancy, the determination of tax policy actually causes a decrease in tax revenue. Then, if the coefficient of buoyancy and coefficient of elasticity are the same, it can be said that the policy are relatively have few or have no impact on tax revenue.

Based on the analysis of VAT elasticity and buoyancy, VAT is inelastic but relatively buoyant. The coefficient of elasticity of VAT revenue is less than one. This

Table 5 Tax Elasticity and Buoyance in Several Other Countries

\begin{tabular}{llllll}
\hline No & Country & $\begin{array}{l}\text { Tax } \\
\text { Elasticity }\end{array}$ & $\begin{array}{l}\text { Tax } \\
\text { Buoyancy }\end{array}$ & $\begin{array}{l}\text { Government } \\
\text { Tax Effort }\end{array}$ & Researcher's name \\
\hline $\mathbf{1}$ & Kenya (VAT) & 0.53 & 0.88 & $67 \%$ & $\begin{array}{l}\text { Timothy C Okech (study period 1986- } \\
\text { 2009) }\end{array}$ \\
\hline $\mathbf{2}$ & Ghana (VAT) & 1.11 & 1.2 & $8 \%$ & $\begin{array}{l}\text { Daniel Kwabena Twerefou (1985-2007 } \\
\text { research period) }\end{array}$ \\
\hline $\mathbf{3}$ & Uganda (VAT) & 1.13 & 1.35 & $19.70 \%$ & $\begin{array}{l}\text { Muwangan Lawrence ( 1980- } \\
\text { 2008 research period) }\end{array}$ \\
\hline $\mathbf{4}$ & $\begin{array}{l}\text { Thiland (Good } \\
\text { and Service } \\
\text { Tax) }\end{array}$ & 0.94 & 0.71 & $-24 \%$ & $\begin{array}{l}\text { Pupongsak Suparerk (study period } \\
\text { 1972-2006) }\end{array}$ \\
\hline $\mathbf{5}$ & $\begin{array}{l}\text { Malaysia } \\
\text { (Sales Tax) }\end{array}$ & 1.08 & 0.83 & $-23 \%$ & $\begin{array}{l}\text { Pupongsak Suparerk (study period } \\
\text { 1972-2006) }\end{array}$ \\
\hline $\mathbf{6}$ & $\begin{array}{l}\text { Philippines } \\
\text { (Good and } \\
\text { Service Tax) }\end{array}$ & 1.62 & 1.31 & $-19 \%$ & $\begin{array}{l}\text { Pupongsak Suparerk (study period } \\
\text { 1972-2006) }\end{array}$ \\
\hline
\end{tabular}

Source: Author processed

Compared to other countries, the level of VAT revenue elasticity in Indonesia is relatively small. Based on table 4, the level of elasticity of Indonesian VAT revenue is only better than Kenya. Meanwhile, the level of Indonesian VAT revenue buoyancy is still better than Kenya, Thailand and Malaysia. The size of the Indonesian GTE is better than the five countries except Kenya. Compared to other countries in Southeast Asia, Indonesia's VAT receipts are no more elastic than Thailand, Malaysia and the Philippines. However, the level of buoyancy of the three countries is actually smaller than Indonesia. The three countries have a level of buoyancy that is smaller than the level of tax elasticity, in contrast to Indonesia where the level of buoyancy is actually greater than the level of tax elasticity. This explains that the impact of policy changes actually slowed the growth of tax revenues in the three countries.

The interesting thing about the comparison of elasticity and buoyancy between countries is the application of each country's tax types. Countries that implement Value Added Tax (VAT) policies tend to have a greater level of buoyancy than the level of tax elasticity. This explains that the policy change or improvement of tax administration as the government's effort to increase tax revenue has had a positive impact. The four countries (including Indonesia) that apply VAT have a greater level of buoyancy than the level of tax elasticity. In general, the equation of the four countries is explains that VAT revenue growth is not responsive to the growth of the tax base (in this case GDP). VAT revenue is actually buoyant, where the coefficient of VAT revenue buoyancy is more than one. The buoyant VAT receipts explained that the policy adopted by the government on VAT had a positive impact on revenue. Although VAT receipts are not elastic, policies implemented in the aggregate can increase VAT revenues. 
increase (although VAT revenues remain not buoyant). Compared to Kenya, Indonesia has several similarities. According to Worldbank data for 2017, the two countries had an average economic growth of above 4 percent during 1986 to 2017 (World Bank, 2017). Kenya's average economic growth is 4.01 percent and Indonesia is 5.06 percent. The two countries also implemented tax reforms in the near year of 1986 (tax reform in Indonesia was carried out in 1985). Although the characteristics of the economic, geographic and cultural structures of the two countries are different, the tax reforms of the two countries are relatively similar, one of which is the application of the VAT policy mechanism to replace the sales tax policy mechanism.

The GTE measure of VAT Kenya by 60 percent explains that government policies have been implemented quite effectively. Through the Value Added Tax Act in 1990, the Kenyan government implemented a VAT tariff policy of 16 percent (standard rate), 12 percent and 0 percent. In 2003, the Kenyan government began introducing VAT Withholding. This tax collection system by government agencies is able to have a significant impact on VAT revenue, which contributes 40 percent of total VAT revenue in 2009 (Nada and William, 2009). Other tax policies that have a significant impact are the application of the Electronic Tax Register (ETR) in 2005 to improve administrative efficiency, reduce tax avoidance and increase tax accountability (Kenya Revenue Authority, 2007).

Considering the size of the GTE Indonesia during the study period was only 30.75 percent, the VAT policy adopted by the Kenyan government can be a comparison in the modeling of tax policy in Indonesia. VAT policy and administration in Indonesia still needs to be improved and improved. As a developing country, the GTE gap between the governments of Indonesia and Kenya is a signal that changes in policy and administration to increase VAT revenue are the government's priority agenda.

The level of tax elasticity and buoyancy in developing countries is an important implication of tax policy planning as a source of funding in the provision of infrastructure, public spending and investment (Jain, 1969) Under such conditions, an ideal tax system structure is elastic. An elastic tax system is an indicator of sustainable economic growth, which generally reflects the provision of socio-economic infrastructure and maintenance (Ouanes and Thakur, 1997). An elastic tax system does not require repeated and unexpected policy changes that can affect public trust and performance (Nurhidayati, 2015).

An inelastic tax system requires repeated policy changes. This is needed to balance government spending. During 1985 to 2017, growth in VAT revenue in Indonesia was inelastic. VAT receipts as one of the largest sources of government revenue are demanded to be able to contribute adequately. This condition will force the government to repeatedly command policy changes at the level of the Law or to technical regulations. As a result, repeated tax policy changes can have an impact on economic activity. In-During the 1985 to 2017 period, the policy change had a positive impact as reflected by the onelevel VAT revenue collection buoyancy.

However, the elasticity and buoyancy of taxes can illustrate the weaknesses of the tax structure (Cotton, 2012). The level of elasticity that is less than one reflects weaknesses in the structure of VAT revenue in Indonesia during the study period. VAT receipts that are not elastic indicate the ability of the tax system to maximize the tax base in a sustainable manner. These weaknesses are broadly based on the fact that there is still a tax base and tax potential that the administration system has not yet reached. Factors causing inelastic acceptance of VAT are the many exemptions, both VAT subjects and objects, the existence of tax incentives, the low level of tax compliance and the weak tax administration (Milwood, 2012). In fact, these factors have caused distortions in the taxation system, thus hampering tax base as the economy grows.

Basically, the tax policy adopted by the government is aimed at reducing the effects of disincentives on economic activity (Jain, 1969). Tax policy should be able to increase tax revenue through increased economic activity. However, the VAT exemption policy has eliminated about 40 percent of tax base (Adiansyah, 2015). The statement is in contrast to the purpose of implementing the tax policy. This is indeed possible because the tax policy is not entirely appropriate. It still allows for weaknesses that have a negative impact. The annual level of buoyancy can be applied to get a more comprehensive picture of VAT policy and the structure of VAT revenue.

Figure 2 Buoyancy Rate per Year

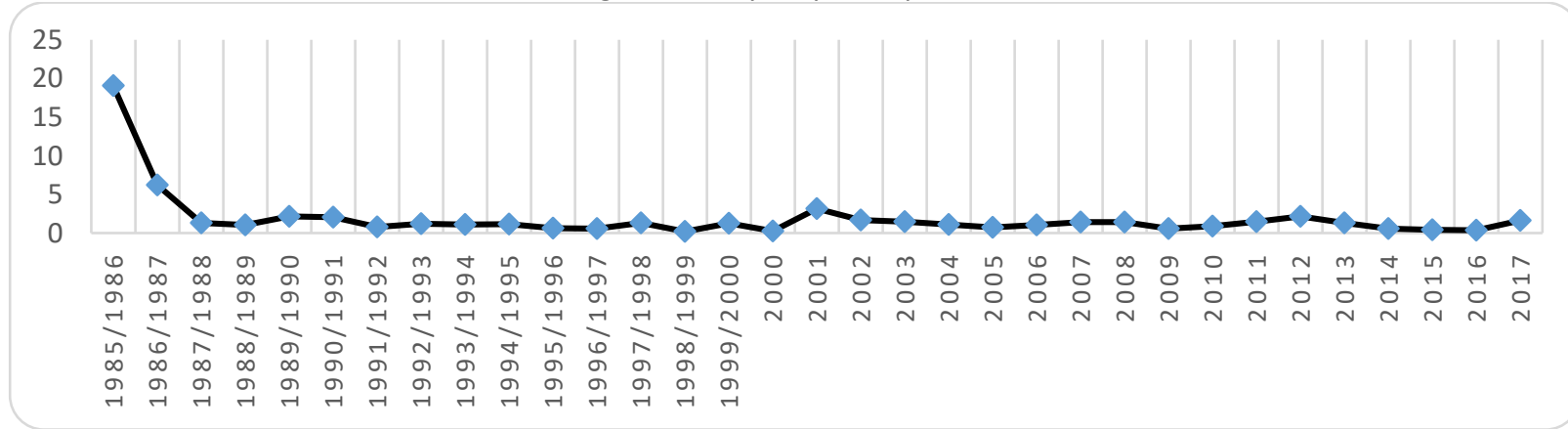

Source: Author Processed 
Based on Figure 2 the highest annual buoyancy rate occurred in 1985/1986. In 1985/86, the growth in VAT revenue was greater than the growth of its tax base. The level of buoyancy indicates a value of more than one where the tax reform policy through the application of Law No. 8 of 1983 is appropriate and has a positive impact on VAT revenue. This explains that the application of the VAT policy mechanism to replace the sales tax policy mechanism is appropriate. Sales tax receipts in 1984/1985 were 837.5 billion rupiahs. After the application of the VAT policy, tax revenues in 1985/86 amounted to 2,190.8 billion rupiahs.

The sales tax base and VAT are the same, namely consumption. However, based on the level of VAT buoyancy, VAT is more effective in responding to the tax base than the sales tax. The characteristic of VAT is that it eliminates the imposition of double taxation in the consumption chain and is only imposed on value added goods and services so that taxation is more evenly distributed and does not hamper the growth of the tax base. In accordance with the Financial Note 1985/1986, with the adoption of new tax regulations (especially the new VAT Law), the government hopes to increase the sense of community participation to play an active role and contribute to participate in development through taxation.

Changes to the VAT policy were repeated in 1995. In 1995, the government actually implemented Law number 11 of 1994 concerning Amendment to Law Number 8 of 1983 concerning Value Added Taxes on Goods and Services and Sales Tax on Luxury Goods. The main points of the change in tax policy are changes in VAT rates and expansion of the scope of taxable services (imposition of VAT on logging services, security services, goods moving services, party management and consulting services, river port services, river cargo expedition services and show host services). Changes to the VAT policy have had a significant impact. This can be seen in the annual level of buoyancy from 1986 to 2000 where there were two times the acceptance of VAT in buoyant nature, namely in 1997 and 1999. In 1997 the acceptance of VAT was buoyant as a result of changes in the previous VAT policy or there was a lag of policy impact for two years. In 1999, VAT revenues were buoyant as a result of the government's actions to improve the economy from the crisis through fiscal and monetary policies. With fiscal and monetary improvements, the Indonesian economy began to recover so that consumption flows and purchasing power of the people were maintained and VAT receipts returned positive.

The lowest level of buoyancy occurred in 1998 and 2000. 1998 was the year in which Indonesia experienced a multi-dimensional crisis that began with the economic crisis. During the economic crisis, people's purchasing power fell due to rising prices of goods and services that were not accompanied by an increase in income. This situation causes VAT receipts to decrease. In 2000, the government also imposed a VAT free policy for entrepreneurs carrying out activities in the integrated economic development area (KAPET). In addition to the free taxation facility, the government also determines the tax facilities borne by the government for the submission of several VAT objects. The taxation facility will eliminate the tax base, causing a loss of potential VAT revenue. These results are in accordance with the government's estimation contained in the Financial Note 1995/1996, the government has realized that changes in tax policy will cause a slowdown in the growth of VAT revenue. However, in the medium and long term, the government believes that state revenue from the tax sector can be increased more.

Reflecting on the multi-dimensional crisis that occurred in 1998, the government began to reform in various fields. One of the improvements made is a change in tax policy. The improvement of VAT administration was carried out by amending Law Number 11 of 1994 as amended by Act Number 18 of 2000. The principal amendments to the Act include changes in several types of goods that are not subject to tax, changes in VAT tariffs, enforcement of sales invoices as a tax invoice. In addition to the law, the government has established an intensification and extensification policy as stated in the 2001 financial memorandum, namely the elimination of VAT exemption facilities for certain goods, retail taxpayer canvassing programs and the exemption of VAT objects on imported goods. Changes in tax policy that were made turned out to have a positive impact on VAT receipts. This is represented by the level of buoyancy after 2000 which is above the number one.

However, after 2001 the level of buoyancy has decreased which indicates a slowdown in VAT revenue growth. The lack of elastic acceptance of VAT can be caused by policy changes related to Small Entrepreneur limits. Since January 1, 2000, the limit for small entrepreneurs to deliver Taxable Goods is no more than 360 million and no more than 180 million for Taxable Services. That value increased from the previous 240 million for BKP and 120 million for JKP. In 2003, the restriction of small-scale entrepreneurs was revised through KMK 571 / KMK.03 / 2003. The regulation regulates small entrepreneurs, namely entrepreneurs who during the fiscal year handed over BKP and JKP with a total gross circulation and or gross revenue of not more than 600 million rupiahs. The policy change is a tax exemption on the subject of VAT, thereby eliminating the tax base and causing loss of potential VAT revenue.

What needs to be observed is the reduction of in the level of VAT revenue buoyancy after 2003 and 2007. In the two years, the government has made tax policy changes related to the exemption of VAT objects for the import of capital goods, raw materials or supporting materials. Exemption of VAT objects for imported goods is regulated in Government Regulation number 38 of 2003 and Government Regulation number 31 of 2007 . The purpose of the enactment of this rule is to reduce the cost of compliance with VAT for entrepreneurs. The policy change is an exemption facility for VAT objects. The 
enactment of this regulation actually reduces the VAT basis and raises the potential loss of VAT revenue. Based on BPS data in 2017, for the last fifteen years around 70 percent of imports in Indonesia were imports of capital goods, raw materials or supporting materials. As a result, the potential VAT revenues from imports will be lost. Accordingly, there was a slowdown in growth in VAT revenue the year after the enactment of the regulation.

The revised PPN administration was revised in 2009. The Government made changes to Law Number 18 of 2000 as amended by Law Number 42 of 2009. The principal changes to the VAT policy in the Act were changes in VAT objects, not objects to tax, VAT administration and VAT facilities. In 2010 there was a growth in VAT revenue that was greater than its tax base. Changes in tax policy have a positive impact on tax revenue, which is reflected in a buoyancy rate greater than one in 2010. In addition, the government has succeeded in implementing the sunset policy in 2008, namely the policy of providing tax facilities in by eliminating tax administration sanctions in the form of interest on late payment of tax underpayments. This policy only applies in the specified year. The successful implementation of the sunset policy helped increase VAT buoyancy in 2009.

However, the growth in VAT revenues did not last long. After 2012, VAT receipts experienced a slowdown in growth from their tax base as reflected in the level of buoyancy below one. This condition is a result of the implementation of PPN's Government Borne Facility (PPN Ditanggung Pemerintah/ DTP) policy. It can be said, the PPN DTP facility policy actually erodes the rate of VAT receipt because the subject of VAT in real terms does not pass the limit of VAT payments. In addition, the enactment of the Minister of Finance Regulation number 197 / PMK.03 / 2013 concerning restrictions on business distribution for entrepreneurs also has a negative impact on the growth of VAT revenues. The regulation regulates small entrepreneurs, namely entrepreneurs who during the fiscal year handed over BKP and JKP with a total gross circulation and or gross revenue of not more than 4.8 billion rupiahs. This policy change has eroded the subject of VAT, resulting in the potential loss of potential VAT revenue. The growth in VAT revenues has become unresponsive to the growth of the tax base.

The government has tried to improve the administration of VAT through PMK number 73 / PMK.03 / 2012 regarding the improvement of the new Taxable Entrepreneur Regulation (PKP). In that year, the government through the Directorate General of Tax (DGT) verified PKP data and revoked 423,274 PKP data because it did not meet the subjective and objective PKP requirements. Verification of PKP data through reexamination including the truth of business activities and the location of business activities carried out by PKP. These policies have not yet had a significant impact on VAT buoyancy seen in the level of buoyancy after 2012 below the number of one.
The development of information technologybased tax services is one important thing in implementing tax reforms (Mahon, 1998). In 2014, the government developed the e-Nofa and e-Invoicing applications. The eNofa application is a follow-up to the implementation of PER-24 / PJ / 2012 regarding the shape, size, procedures for rectification or replacement, and the procedure for canceling a tax invoice in the form of giving a Tax Invoice Serial Number (NSFP) automatically through an electronic system provided DGT. One aimed of this application is to reduce tax fraud in the form of fictitious tax invoices. The eNofa application began to be implemented nationally in 2015.

The e-Invoicing application is an inseparable part of DGT's efforts to overcome fraudulent fictitious tax invoices as well as increase tax accountability and transparency in order to improve VAT administration. The e-Invoicing application is a tax invoice created through an electronic system provided by DGT.Application of eInvoicing was factually implemented in all regions of Indonesia in 2016. In addition to the development of technology-based services, the government through the DGT also formed a task force (task force) handling Tax Invoice that is not Based on Actual Transactions (FP TBTS) in 2014. Work results from The FP TBTS task force in 2015 based on the DGT press release was a clarification of FP TBTS worth 2,642 billion rupiahs. This technology development and task force contributed to improving VAT administration as reflected in the increasing level of buoyancy in 2016.

The responsiveness of VAT revenue to the tax base also increased to its peak in 2017. In 2017, VAT revenue growth was greater than GDP growth. This achievement gave a positive signal for several new tax policies implemented. The government implemented a tax amnesty policy from mid 2016 to mid 2017. With the amnesty policy, the government gave a good signal to taxpayers to be given a remission facility so that taxpayers would be willing to improve tax compliance and be willing to make redemptions on tax debt and assets or other income that has not been reported. The amnesty policy is expected to add a new tax base which in the long run can become the potential for new VAT receipts. In addition to tax amnesty, the government is also starting an automatic information exchange (AEol) policy with several countries. The purpose of this automatic information exchange policy is for tax compliance purposes. This policy also gives a signal to taxpayers that tax institutions have strong authority over information so that it is very difficult for taxpayers to hide information. Basically information is used as a tax base that can be a potential tax revenue.

\section{Level of Government Tax Effort VAT}

Buoyancy per year gives a comprehensive overview of relevant changes in tax policy. From 1985 to 2017, there was a fluctuation in responsiveness of VAT receipts. In aggregate, the government has changed the tax policy on VAT and had a positive impact on VAT revenue. 
Figure 3 Comparison of the Level of Elasticity and Buoyancy

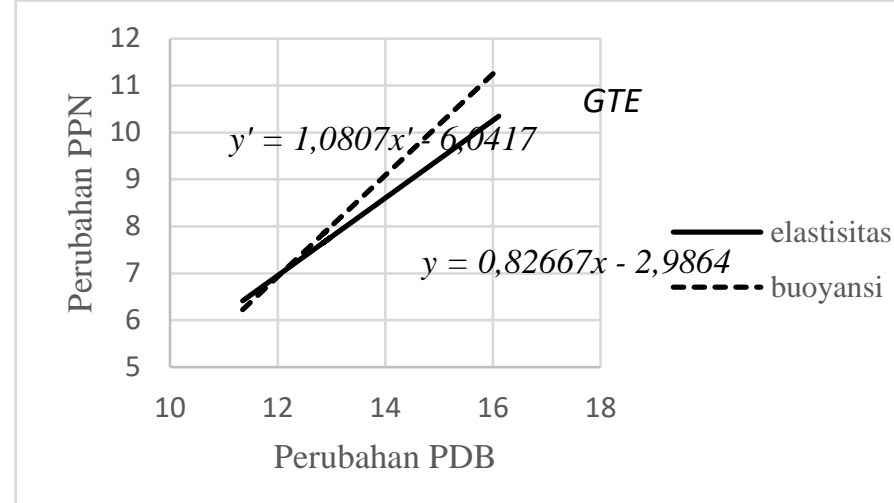

Source: Author processed

The GTE measurement results show a value of 30.75 percent. The policy change and improvement in VAT administration by the government through the DGT has had a positive impact so that VAT receipts have become more responsive 30.75 percent compared to the automatic growth of VAT receipts.

Based on Figure 3 the gap that occurs between the buoyancy line and the elasticity line is called the Government Tax Effort measurement. The coverage of the GTE area in figure IV.5 shows that government efforts through policy changes and improved VAT administration have been able to increase VAT revenue. The effort is reflected in Figure IV.5, namely the change in the $y$ line to the $y$ 'line where the $y$ line shows the level of elasticity and the $y$ line shows the level of buoyancy. Thus, the area of change on the $y-y$ ' axis shows GTE's efforts as an increase in VAT revenue during the study period.

Government efforts during the research period through improvements to the administration system and tax discretion policy have positively increased VAT revenue. However, there is still room for improvement. There is still an unreached tax base or a tax base that was lost due to VAT exemption. This should be a concern of the government considering that the main challenge of the source of government funding is sustainable tax revenue in the situation of global market dynamics and technological developments. The government needs to review the existing tax policies. Thus, the government is expected to be able to form a more competitive tax structure, especially VAT. A competitive tax structure is able to attract capital, expertise and technology that are important for maximizing economic growth (Olukuru and Mandela, 2017).

\section{CONCLUSIONS AND SUGGESTION}

The size of the Government Tax Effort (GTE) is a measure of efforts to improve the administration of the taxation system by the government in a certain period of time as a result of implementing a policy. Considering that the achievement of GTE Indonesia during the research period was 30.75 percent, the DGT was demanded to be able to increase these achievements. Several attempts to improve the quality of tax administration related to VAT have been carried out in the past five years, namely reregistration of Taxable Entrepreneurs (PKP), the use of eInvoices, and the task force for handling tax invoices not based on actual transactions. However, DGT needs to continue to improve information technology services, improve VAT policies that are more attractive, especially to form a more competitive VAT structure so as to be able to attract capital, expertise and technology that are important for maximizing economic growth.

This study did not use sectoral VAT revenue data. This limitation was due to incomplete data on sectoral VAT receipts during the study period. The use of sectoral VAT revenue data can provide a more comprehensive picture of the tax structure of each economic sector so that it can be seen the level of elasticity and VAT buoyancy for each economic sector.

\section{REFERENCES}

Ardiansyah, Benny G. 2015. Pembebasan PPN Kebijakan Produktif atau Kontradiktif. Media Keuangan Kementerian Keuangan.

Al-Firdaus, Farid. 2017. Studi Eksploratif Penanganan Faktur Pajak yang Tidak Berdasarkan Transaksi yang Sebenarnya. Indonesian Tax Journal Vol.1.

Ariefianto, Moch. 2012. Ekonometrika: Esensi dan Aplikasi Menggunakan Eviews. Jakarta: Penerbit Erlangga.

Ariyo, A. 1997. Productivity of the Nigerian Tax System. AERC Research Paper No.74.

Aslichati, Lilik, Bambang Prasetyo, dan Prasetya Irawan. 2011. Metode Penelitian Sosial. Jakarta: Penerbit Universitas Terbuka.

Atikah, Ika. 2012. Teori Elastisitas Permintaan dan Penawaran. Ilmu Ekonomi

Badan Pusat Statistik. 2016. www.bps.go.id. Portal Badan Pusat Statistik. www.bps.go.id (diakses 2 Juli 2018).

Badan Pusat Statistik. 2017. BPS. Portal BPS. https://www.bps.go.id/subject/11/produkdomestik-bruto--lapangan-usaha-.html (diakses 27 Juni 2018).

Bothole, Thuto D dan Tanumopriye J Agiobenebo. 2006. The Elasticity and Buoyancy of the Bostwana Tax System and Their Determinants.

Cnossen, Sjibren. 1989. Broad-Based Consumption Taxes: VAT, RST, or BST? Australian Tax Forum 6 325-370.

Cotton, J. J. 2012. The Buoyancy and Elasticity of Non-Oil Tax Revenues in Trinidad and Tobago (1990-2009). Central Bank of Trinidad and Tobago Working Paper

Cryer, Jonathan D. 1986. Time Series Analysis. Boston: PWS Publisher.

Ehdaie, Jaber. 1990. An Econometric Method for Estimating the Tax Elasticity and the Impact on Revenues of 
Discretionary Tax Measures (Applied to Malawi and Maratius). Public Economics WPS 334.

Gale, William G dan Benjamin Haris. 2011. A Value-Added Tax for The United States: Part of The Solution. The VAT Reader Tax Analyst 64-82.

Ghozali. 2013. Aplikasi Analisis Multivariate Dengan Program SPSS. Semarang: Universitas Diponegoro.

Haughton, Jonathan. 1998. Estimating Tax Buoyancy, Elasticity, and Stability. African Economic Policy Paper Discussion 1-8.

Hidayat, Asrul dan Tubagus Chairil Amachi. 2013. Analisis Penerimaan Pajak dengan Pendekatan Produk Domestik Bruto Sektoral. Universitas Indonesia

International Monetary Fund. 2017. IMF. Portal IMF. http://www.imf.org/external/pubs/ft/fandd/basi cs/gdp.htm (diakses 27 Juni 2018).

Jain, M. M. 1969. Income Elasticity of Indian Tax Structure 1955-56 to 1965-66. Economic and Political Weekly 769-772.

Jenkins, Glenn P, Kuo Yan Chun, dan Gangadhar P Shukla. 2000. Tax Analysis and Revenue Forecasting. Harvard Institute for International Development

Jenkins, Glenn P dan Chun Yan Kuo. 2000. A VAT Revenue Simulation Model for Tax Reform in Developing Countries. World Development Vol.28 763-774.

Kargbo, Brima I. B. dan Festus O. Egwakhide. 2012. Tax Elasticity in Sierra Leone: A Time Series Approach. National Journal of Economics and Financial Issues Vol.2 432-447.

Kenya Revenue Authority. 2007. Domestic Taxes Department: Value Added Tax at Glance. Taxpayer Information and Education Servises

Lawrence, Muwanga. 2011. Adequacy of Tax Revenue and The National Budget Deficit in Uganda Before and After The Tax Reforms (1980-2008). Makarere University's Institutional Repository

Leuthold, J. 1986. Tax Buoyancy vs Elasticity in Developing Economy. Faculty Working Paper

Mahon, J. E. 1998. Tax Reform and Its Determinants in Latin America: Implications for Theories of State Development. Paper prepared for the meeting of the Latin American Studies Association

Mankiw. 2015. Macroeconomics. Cambridge: Harvard University.

Mansfield, C. Y. 1972. Elasticity and Buoyancy of a Tax System: A Method Applied to Paraguay. IMF Staff Paper vol. 19

Mardiasmo. 2011. Perpajakan Edisi Revisi 2011. Jakarta: Penerbit Andi.

Milwood, T. T. 2012. Elasticity and Buoyancy of the Jamaican Tax System. Fiscal and Economic Programme Monitoring Development Bank of Jamaica

N.Choudry, N. 1979. Measuring the Elasticity of Tax Revenue: A Divisia Indeks Approach. IMF Staff Papers Vol. 26.

Nachrowi, Djalal dan Hardius Usman. 2006. Pendekatan
Populer dan Praktis Ekonometrika Untuk Analisis Ekonomi dan Keuangan. Jakarta: Lembaga Penerbut Fakultas Ekonomi Universitas Indonesia.

Nada, O. E. dan J. William. 2009. Tax Reform In Kenya: Policy and Administrative Issues. Initiative for Policy Dialogue Working Paper Series October 2009

Nurhidayati. 2015. Estimasi Elastisitas dan Buoyancy Pajak Pertambahan Nilai. Info Artha Politeknik Keuangan Negara STAN

Okech, Timothy C. dan Peter G. Mburu. 2011. Analysis of Responsiveness of Tax Revenue to Changes in National Income in Kenya Beetween 1986-2009. International Journal of Business and Social Science Vol.2.

Olukuru, John dan Barrack Mandela. 2017. Tax Buoyancy: A Comparative Study Between Kenya and South Africa. Development Finance 51-72.

Omondi, Francis dan Seth Gor. 2014. VAT Reform and Revenue in Kenya (1990-2010). Researchjournali's Journal of Economics 2347.

Organisation for Economic Co-operation and Development. 2001. OECD. Portal OECD. https://stats.oecd.org/glossary/detail.asp?ID=116 3 (diakses 27 Juni 2018).

Osoro, Nehemiah E. 1993. Revenue Productivity Implication of Tax Reform in Tanzania. African Economic Research Consortium

Ouanes, Abdessatar dan Subhash Madhav Thakur. 1997. Macroeconomic Accounting and Analysis in Transition Economies. Washington: International Monetary Fund.

Priambodo, Wahyu. 2013. Estimasi Tax Elasticity, Tax Buoyancy dan Government Tax Effort untuk PPN dan PPnBM di Indonesia Menggunakan Metode Indeks Divisia: Periode Tahun Anggaran 1985/1986 - 2011. Tesis

Pupongsak, Suparerk. 2009. The Effect of Trade Liberalization on Taxation and Government Revenue. Phd Thesis University of Birmingham

Rosdiana, Haula, Edi Slamet Irianto, dan Titi Muswati Putranti. 2012. Teori Pajak Pertambahan Nilai: Kebijakan dan Implementasinya di Indonesia. Bogor: Ghalia Indonesia.

Sekaran, Uma. 2006. Metodologi Penelitian untuk Bisnis: Buku 1. Jakarta: Penerbit Salemba Empat.

Sekaran, Uma. 2006. Metodologi Penelitian untuk Bisnis: Buku 2. Jakarta: Penerbit Salemba Empat.

Singer, Neil M. 1968. The User of Dummy Variables in Estimating The Income Elasticity of State Income Tax Revenues. National Tax Journal Vol.21 200204.

Sjafri, Rika S. 2006. Analisis Tentang Penerimaan Pajak Sebagai Fungsi dari Produk Domestik Bruto Kaitannya dengan Tax Buoyancy dan Elastisitas Pajak di Indonesia. Tesis

Soelistianingsih, Lana. 2017. Okezone. Portal Okezone. 
www.okezone.com (diakses 25 Juni 2018).

Sugana, Rubino dan Asrul Hidayat. 2014. Analisis Potensi dan Kesenjangan Pajak Pertambahan Nilai di Indonesia. Jurnal Ekonomi dan Pembangunan Indonesia Vol.15 1-40.

Sugiarto. 2012. Statistika Ekonomi dan Bisnis. Tangerang Selatan: Penerbit Universitas Terbuka.

Sugiyono. 2016. Metode Penelitian Kuantitatif, Kualitatif, dan $R \& D$. Jakarta: Alfabeta.

Sukardji, Untung. 2014. Pokok-Pokok Pajak Pertambahan Nilai Indonesia: Edisi Revisi 2014. Jakarta: Penerbit Rajawali Pers.

Suska. 2011. Fungsi Pajak Penghasilan Sebagai Automatic Stabilizer.

Symansky, S. A. dan T Bansgard. 2009. Automatic Fiscal Stabilizer. IMF Working Paper SPN/09/23.

Tait, Alan A. 1999. The Encyclopedia of Taxation and Tax Policy. International Monetary Fund

Tanzi, Vito. 1989. The Impact Macroeconomic Policies on The Level of Taxation and The Fiscal Balance in Developing Countries. Palgrave Macmilan Journal Vol.36 No.3 633-656.

Thac, Cao D. dan David Lim. 1984. Papua New Guinea's Tax Performance. World Development 451-459. 